\title{
Angiodema due to oral acitretin and isotretinoin
}

\author{
Angioedema por acitretina e isotretinoína oral
}

\author{
Roberto Rheingantz da Cunha Filho ${ }^{1}$ \\ Juliano de Avelar Breunig 3
}

\author{
Hiram Larangeira de Almeida $\mathrm{Jr}^{2}$
}

\begin{abstract}
Angioedema may be caused by nonsteroidal antiinflammatory drugs, angiotensin- converting enzyme inhibitors, radiocontrast media, antibiotics, sea food etc. It can involve an allergic (IgE-mediated) or non-allergic hypersensitivity reaction, both with a similar clinical presentation. While angioedema due to isotretionin has been described previously, this is the first description of angiodema due to acitretin. We report two uncommon cases of palpebral and labial angiodema due to retinoids, by acitretin and oral isotretinoin respectively: a 48-year-old man with psoriasis and a 24 -year-old woman with severe acne resistant to antibiotics and topical drugs. In both cases the reaction persisted throughout treatment with these drugs, but resolved quickly after discontinuation. Reintroduction of the drugs brought on angioedema again.
\end{abstract}

Keywords: Acitretin; Angioedema; Edema; Isotretinoin

Resumo: Angioedema pode ser causado por diversos fármacos como : antiinflamatórios nãoesteroidais, inibidores da ECA, contrastes, antibióticos e frutos do mar, entre outras causas. Pode ser uma reação alérgica, mediada por IgE, ou não-alérgica, com apresentações clínicas semelhantes. Angioedema por isotretinoína já foi relatado, mas não por acitretina. Relatamos dois casos, uma com angioedema palpebral e um labial, por acitretina e isotretinoína, respectivamente: um paciente de 48 anos com psoríase e uma paciente de 24 anos com acne resistente à terapia convencional. Em ambos casos a afecção persistiu durante o tratamento, resolveu com a interrupção e recidivou com reexposição.

Palavras-Chave: Acitretina; Angioedema; Edema; Isotretinoína

Recebido em 20.01.2011.

Aprovado pelo Conselho Consultivo e aceito para publicação em 17.03.2011

* Study undertaken at the Catholic University of Pelotas (UCPel) and Oeste de Santa Catarina University (UNOESC), Joaçaba (SC), Brazil. Conflito de interesse: Nenhum / Conflict of interest: None Suporte financeiro: Nenhum / Financial funding: None

Master's Degree in Health awarded by the Catholic University of Pelotas (UCPel), Dermatologist in private clinic and Professor of Clinical Surgery and Probation Ambulatory at the Oeste de Santa Catarina University (UNOESC), Joaçaba (SC), Brazil.

PhD in Dermatology, Associate Professor of Dermatology at the Catholic University of Pelotas (UCPel) and Federal University of Pelotas (UFPel), Pelotas (RS), Brazil.

Master's Degree in Health awarded by the Catholic University of Pelotas (UCPel), Dermatologist, Professor of Dermatology at the University of Santa Cruz (UNISC), Santa Cruz do Sul (RS), Brazil. 


\section{INTRODUCTION}

Retinoids are widely used to treat many conditions. Acitretin is useful for controlling extensive and incapacitating psoriasis, while isotretinoin is the best choice for patients with severe recalcitrant nodular acne unresponsive to conventional therapies. A wide range of adverse effects may occur, such as cheilitis, xerosis, retinoid dermatitis, dyslipidemia, desquamation, photosensitivity, paronychia, pyogenic granuloma and onycholysis, but these are normally easy to control. Rare serious side effects have been described such as pancreatitis, seizures and cerebral pseudotumor. ${ }^{1,2,3}$ Mood changes, depression, suicide risk and bowel inflammatory disease are also controversial outcomes. ${ }^{4,5}$ Angiodema may be caused by various drugs, foods and vaccines: e.g. nonsteroidal antiinflammatory drugs, angiotensin-converting enzyme inhibitors, radiocontrast media, antibiotics, aspirin, sea food ${ }^{6,7}$ etc. Rare cases of angioedema and urticaria have been reported due to isotretinoin, but to date not by acitretin. ${ }^{9}$ We report two cases of angioedema due to acitretin and isotretinoin.

\section{CASE REPORT}

A 48-year-old man was treated with acitretin $25 \mathrm{mg} /$ day for palm and sole psoriasis since he suffered from hypertension and was unable to tolerate methotrexate. He reported that on Day 2 after starting therapy bilateral periorbital edema appeared (Figure 1). He had no previous history of urticaria or any drug reactions. Blood tests were normal, including $\mathrm{C} 1$ esterase inhibitor. Also tested negative for ASO, HCV, HIV and parasitological feces. He had no other symptoms. The angioedema subsided completely a few days after acitretin was discontinued. When acitretin was restarted he had a relapse of the angioedema. At 3 years follow-up there was no recurrence of angioedema, thereby excluding food allergy. Our second case was that

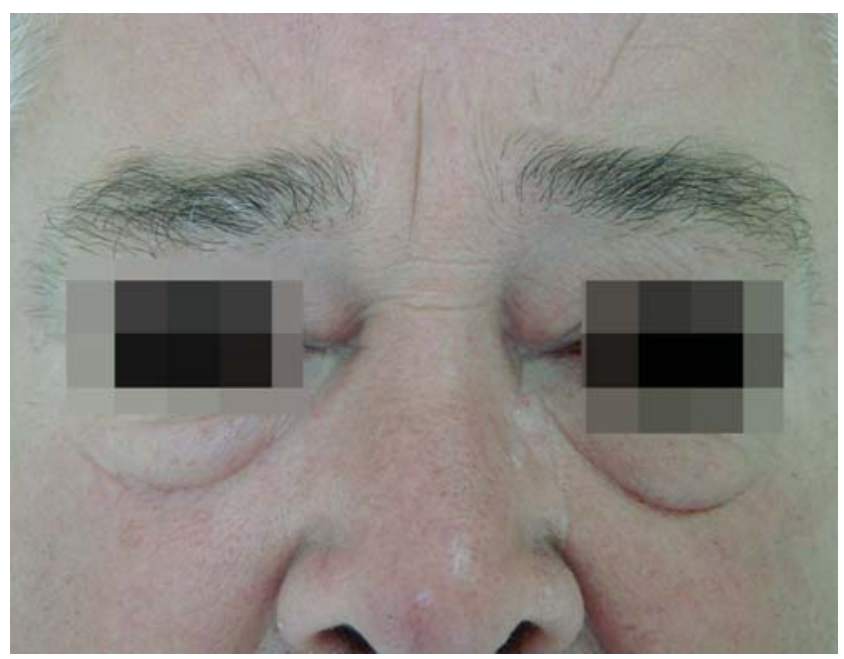

FIGURE 1: Angiodema due to acitretin - bilateral periorbital edema of a 24-year-old woman with mild acne, unresponsive to other treatments. After pregnancy exclusion, she received oral isotretinoin $20 \mathrm{mg}$ per day. On Day 2 of therapy a sudden lip edema was observed. Since she was no taking any other medication, isotretinoin was discontinued and the skin lesion controlled. As in the first case, following re-exposure to the drug the lesions relapsed. Follow-up at 2-years showed no relapses, again indicating that a food allergy was not responsible for the condition.

\section{DISCUSSION}

Angioedema is a variant of urticaria. It may be acquired from hereditary $\mathrm{C} 1$ esterease inhibitor deficiency or from certain drugs and foods. The pathogenesis is complex and variable. It can involve an allergic (IgE-mediated) or non-allergic hypersensitivity reaction and may include pseudoallergy, idiosyncrasy, IgE-mediated hypersensitivity and occasionally IgG antibodies. IgE-mediated immediate type hypersensitivity reactions have been established. The penicillins have been extensively investigated and appropriate diagnostic tests such as skin tests and determination of specific IgE with standardized allergens are available, but the pathogenesis of drug-induced urticaria and angioedema is rarely clear. ${ }^{6,78}$

No reports exist to date of angioedema or urticaria associated with acitretin and only a few cases caused by isotretinoin have been reported. ${ }^{3,9}$ In both our cases, we attributed the cause of angioedema to the oral retinoid therapy given that the patients were not taking other medications, no evidence existed of suspicious food intake at the time the lesions developed.

While angioedema appeared shortly after retinoid intake, it nevertheless disappeared after the drug was discontinued and then recurred when therapy restarted, indicating that retinoids could indeed cause angioedema. It is also possible that additives in the capsules might be involved (beeswax, butylated hydroxyanisole, edetate disodium, hydrogenated soybean oil flakes, hydrogenated vegetable oil, microcrystalline cellulose and soybean oil). Gelatin capsules contain glycerin and parabens (methyl and propyl), with the following dye systems: $10 \mathrm{mg}$ - iron oxide (red) and titanium dioxide; $20 \mathrm{mg}$ - FD\&C Red No. 3, FD\&C Blue No. 1, and titanium dioxide; $40 \mathrm{mg}$ - FD\&C Yellow No. 6, D\&C Yellow No. 10, and La Roche-type titanium dioxide. These additives in drugs and foods have not been found to produce angioedema.

We suggest that retinoids are probably the cause of angioedema given that no allergies manifested in either patient before or after receiving acitretrin or isotretinoin. Further study is required to discover the true pathogenesis. 


\section{REFERÊNCIAS}

1. Brito MFM, Pessoa IS, Galindo JCS, Rosendo LHPM, Santos JB. Avaliação dos efeitos adversos clínicos e alterações laboratoriais em pacientes com acne vulgar tratados com isotretinoína oral. An Bras Dermatol. 2010:85:331-7.

2. Lee CS, Li K. A review of acitretin for the treatment of psoriasis. Expert Opin Drug Saf. 2009:8:769-79.

3. Scheinfeld N, Bangalore S. Facial edema induced by isotretinoin use: a case and a review of the side effects of isotretinoin. J Drugs Dermatol. 2006;5:467-8.

4. Azoulay L, Blais L, Koren G, LeLorier J, Bérard A. Isotretinoin and the risk of depression in patients with acne vulgaris: a CSE-crossover study. J Clin Psychiatry. 2008;69:526-32.

5. Bigby M. Does isotretinoin increase the risk of depression? Arch Dermatol. 2008;144:1197-9.

6. Hoefnagel JJ, Wehmeijer K, Terreehorst I, van Zuuren EJ. Angio-oedema and urticaria as side effects of frequently used drugs. Ned Tijdschr Geneeskd. 2010;154:A1854

7. Mathelier-Fusade P. Drug-induced chronic urticarias. Ann Dermatol Venereol 2003;130:1S31-4.

8. Bircher AJ. Drug-induced urticaria and angioedema caused by non-IgE mediated pathomechanisms. Eur J Dermatol. 1999;9:657-30.

9. Saray Y, Seçkin D. Angioedema and urticaria due to isotretinoin therapy.J Eur Acad Dermatol Venereol. 2006;20:118-20.
ENDEREÇO PARA CORRESPONDÊNCIA / MAILING ADDRESS: Roberto Rbeingantz da Cunba Filbo, Avenida Santa Terezinha 243, Sala 302. Edifício Centro Profissional, Joaçaba, 89600 O0O Santa Catarina BRAZIL E-mail: robertodermatologista@yahoo.com.br

How to cite this article: da Cunha Filho RR, Almeida Jr HL, Breunig JL. Angiodema due to oral acitretin and isotretinoin. An Bras Dermatol. 2011;86(4 Supl 1):S28-30. 